American Journal of Applied Sciences 4 (1): 8-13, 2007

ISSN 1546-9239

(C) 2007 Science Publications

\title{
Blockade for Career Advancement in Japanese Organization Abroad: The Case of Malaysian Subsidiaries
}

\author{
Raduan Che Rose and Naresh Kumar \\ Graduate School of Management, University Putra Malaysia
}

\begin{abstract}
This study empirically examines the significance of demographic factors and organizational characteristics in influencing the perceived barriers to career advancement of local managers in Japanese subsidiaries. Moreover, significant relationship between stereotype and discrimination and the number of local managers in higher management positions also been analyzed. The perceived barriers were examined through an analysis of 317 local managers working in 41 Japanese subsidiaries in Malaysia. Overall findings suggest that perceived barriers do exist in Japanese subsidiaries in Malaysia and these barriers hinder local managers' career advancement opportunities. Suggestions to trim down the barriers for career advancement among local managers in Japanese subsidiaries have been discussed.
\end{abstract}

Key words: Malaysia, career advancement, Japanese subsidiaries

\section{INTRODUCTION}

The Japanese economic miracle has captured the avid interest of the non-Japanese. Initial interest in Japan's seemingly unique style of decision-making and work organization sprang from the role of management and work in Japan's phenomenal post-war economic growth $^{[1-7]}$. In Malaysia, this interest has been highlighted by the enunciation of the Look East Policy by the former Prime Minister, Tun Dr Mahathir Mohammad, in December 1981. Foreign direct investment (FDI) of predominant investors like Japan has contributed greatly towards Malaysia's economic development ${ }^{[8]}$. The miracle of Japan's economic success is said to be due to its unique Human Resource Management (HRM) style. Tsuda ${ }^{[9]}$ referred to the special features of Japanese management practices such as life-time employment, seniority based wage system, enterprise welfare and enterprise unions as a tightly coherent organic system, stressing that each of the special features does not exist in isolation or as separate entities. However, the transfer of Japanese style HRM in Malaysia like other developing countries is indirect ${ }^{[8]}$. This is because the overriding objectives are mostly economic.

Japanese subsidiaries in Malaysia according to Imaoka ${ }^{[10]}$ emphasized in firm promotion systems, seniority-merit wage systems, human relations between workers and management, long-term oriented on-thejob training, commendation for long service and personnel welfare policies. This is to retain local workers and implement Japanese style management within the sphere of their authority. The distinctive Japanese style HRM practices in Malaysia and other developing countries in most studies ${ }^{[11,12]}$ suggest high degree of control exerted by parent companies over major areas of decision making. Japanese expatriates stationed in subsidiaries control major decisions ${ }^{[13]}$. The presence of expatriates has isolated local managers from the decision making process and thus causing a ceiling impeding their promotion.

Local managers mostly occupy jobs relating to labor and personnel, while their Japanese counterparts occupy all other key positions ${ }^{[14]}$. Some lower positions are even staffed by Japanese junior managers. This strong presence of Japanese expatriates in subsidiaries in developing countries, due to the lack of trust and confidence in local managers, is also known as the 'inferior' local workforce factor ${ }^{[15]}$. Japanese companies are noted to be the most ethnocentric in nature when it comes to their staffing policies. This phenomenon has been observed in Japanese subsidiaries in both developed $^{[16]}$ and developing countries ${ }^{[15,17]}$. The high degree of centralization imposed in major decision making areas in Japanese companies through parent companies or Japanese expatriate managers are one of its characteristics.

Table 1 extracted from Raduan ${ }^{[8]}$, presents the managerial structure according to the functions of local managers and Japanese managers in sixty-nine subsidiaries surveyed. The findings clearly revealed the differently designated responsibilities of local managers and Japanese managers. By looking at Table 1, it can be seen that local managers, majority of whom are male tend to take managerial responsibilities related to local issues or act as 'backstage prompters ${ }^{\text {'[18] }}$. These issues include personnel matters $(74.3 \%)$, liaisons with local people and institutes $(77.5 \%)$ and public relations (74.3\%). At the same time, the Japanese managers dominate important and strategic functions such as strategic planning, finance and production methods.

Corresponding Author: Dr. Raduan Che Rose, Graduate School of Management, Universiti Putra Malaysia, Fax: 60-6038943-4019 
Am. J. Applied Sci., 4 (1): 8-13, 2007

\begin{tabular}{|c|c|c|c|c|c|c|c|c|}
\hline \multirow{2}{*}{$\begin{array}{l}\text { Total } \\
\% \\
\end{array}$} & \multicolumn{3}{|c|}{ Gender } & & \multirow{2}{*}{$\begin{array}{r}\text { Gender } \\
\text { Male } \\
\end{array}$} & \multicolumn{3}{|c|}{ Total } \\
\hline & $f$ & Female & Male & Managerial Functions & & Female & $f$ & $\%$ \\
\hline 74.3 & 55 & 13 & 42 & Personnel Matters & 19 & 0 & 19 & 25.7 \\
\hline 72.5 & 50 & 11 & 39 & Industrial Relations & 19 & 0 & 19 & 27.5 \\
\hline 74.3 & 52 & 13 & 39 & Public Relations & 18 & 0 & 18 & 25.7 \\
\hline 77.5 & 55 & 13 & 42 & Liaisons with outsiders & 11 & 5 & 16 & 22.5 \\
\hline 33.3 & 30 & 7 & 23 & Corporate Planning & 49 & 11 & 60 & 66.7 \\
\hline 47.5 & 38 & 9 & 29 & Finance & 39 & 3 & 42 & 52.5 \\
\hline 36.9 & 28 & 3 & 26 & Production Planning & 47 & 1 & 48 & 63.2 \\
\hline 44.2 & 38 & 3 & 35 & Manufacturing & 47 & 1 & 48 & 55.8 \\
\hline 36.3 & 33 & 11 & 22 & Marketing & 51 & 7 & 58 & 63.7 \\
\hline 74.3 & 55 & 13 & 42 & Legal Matters & 19 & 0 & 19 & 25.7 \\
\hline 55.6 & 434 & 95 & 339 & Total & 319 & 28 & 347 & 44.4 \\
\hline
\end{tabular}

(Source: Extracted from Raduan ${ }^{[8]}$ : Survey Data, 1997 and Ministry of Human Resources, Malaysia.)

Half of the sample indicated that Japanese managers are responsible for corporate planning $(66.7 \%)$, marketing $(63.7 \%)$, production planning $(63.2 \%)$ and manufacturing $(55.8 \%)$. Also, Japanese managers normally have exclusive access to headquarters, thus obtaining advantages in respect of influence and information. Feedback from interviews with local managers indicated that almost all key policies were formulated and serious decisions taken, even before local managers were allowed to voice their opinion. These situations made them doubt the effectiveness of their role in the company because they were excluded from the decision-making process ${ }^{[8]}$.

Therefore, in his research Raduan ${ }^{[8]}$, drew a few general conclusions after examining the managerial structure. Firstly, there seems to be a lack of confidence in the competence of local managers to perform strategic functions especially corporate planning, product planning and finance. Secondly, Japanese subsidiaries rely on local managers mostly for their expertise in knowledge of local culture, environment, labor law and practices. Other issues were also raised during his interviews with local managers. It was reported that the senior Japanese managers to protect Japanese expatriates especially when dealing with sensitive issues concerning local values and culture were using trusted local managers. This leaves local managers with the problem of maintaining balance between two parties in the same organization.

Another important issue is related to career development of local managers within their companies. Quite a number of local managers interviewed by Raduan $^{[8]}$ admitted their chances of promotion to higher positions, especially in areas of corporate planning, production and quality control, have been limited by the presence of many Japanese expatriates. This phenomenon seems to be widespread among Japanese companies in developing countries, where local managers resent the 'bamboo ceiling, ${ }^{[13]}$. The 'bamboo ceiling' similar to the 'rice-paper ceiling' prevents local managers from receiving promotion to upper level positions $^{13,17]}$. In Malaysia, Japanese expatriates are said to fill most of the senior positions and this results in limited opportunities for local managers to be promoted. So it can be said that there is an unofficial ceiling to promotion be it a bamboo ceiling or rice paper ceiling. A barrier does seem to exist. Some local managers even criticized the special treatment received by Japanese managers. This included a higher basic salary, and allowances, other fringe benefits and facilities as well as access to the parent company.

Research hypothesis: Japanese subsidiaries have a unique quality of high degree of centralization and this poses challenges to local managers when operating in a foreign country like Malaysia. One of the prevailing challenges includes perceived barriers, which are apparent or seemingly real obstacles and obstructions in the path to achieve goals and career advancement. In this research, the perceived barriers identified are: access to power and decision-making authority, stereotyping and discrimination, opportunities for promotion, benefits, wages and compensation system, performance appraisal and feedback. These barriers were chosen for this study because they seem to have the most impact on career advancement opportunities of local managers. Previous studies ${ }^{[8,10,19]}$ have shown that these perceived barriers for local managers working in Japanese multinational corporations (MNCs) do indeed exist. Therefore, this study looks into the impact of demographic and organizational factors on the perceived barriers affecting local managers' career advancement opportunities into higher management positions in Japanese firms.

Demographic factors such as age, gender, marital status, academic background and race play a role in career advancement of local managers. It is a wellknown fact that the Japanese like to hire young and fresh graduates who they can mould ${ }^{[20]}$. Also male managers would be preferred compared to female managers. In Japanese firm although education is of importance, past research suggested seniority would earn preference in promotion and career advancement ${ }^{[21]}$. The preference of the race of the local manager is a factor that has not been looked into. The findings of the study may offer new insight if there is any racial preference in working with local managers be it Malay, Chinese or Indian. Thus, the first hypothesis to be tested is: There is no significant relationship between demographic factors and perceived barriers to career advancement.

Characteristics of the organization consist of size, numbers of years in operation, type of ownership and type of industry are also of fundamental importance to this research. All these variables have, to a certain extent, determined the career advancement of local managers in Malaysia. Consequently, it is hypothesized that: There is no significant relationship between characteristics of organization and perceived barriers to career advancement.

Perceived barriers such as stereotypes and discrimination adversely impact on local managers' career progress. Since local managers are perceived as ineffective leaders, they are not assigned line positions, where managers make significant decisions, have access to information and interact with top-level executives who may have an impact on their careers ${ }^{[22]}$. If local managers are not considered to be decision makers and leaders but are perceived merely as support personnel, they would be denied critical information, 
because this would not be seen as relevant to them. These opportunities to learn, grow and develop on the job and gain visibility in the system, help managers to advance to top-level positions ${ }^{[8]}$. However, because local managers in staff positions do not gain these experiences or have the visibility to be identified as key people in the organization with the potential to be successful top managers, their advancement to top-level positions is rare and usually overlooked. Thus, the act of stereotyping and discrimination hinder the progress of local managers to the top.

Opportunities for promotion in terms of benefits and compensation system, performance appraisal and feedback are also denied because of this discrimination. Local managers are excluded from the networks where Japanese managers informally interact with one another, including golf courses, private Japanese managers clubs and so on ${ }^{[19,23]}$. Local managers are also barred from gaining access to key information and resources vital for their advancement. Local managers are generally unaware of the most recent development since they are not a part of the informal group that interacts and exchanges information away from the workplace. This definitely is a handicap and chances of advancement are severely restricted. Hence, the discussion above leads to the construction of the following hypothesis: There is no significant relationship between the extent of stereotyping and discrimination in the organizations and the number of local managers in higher management positions in Japanese subsidiaries.

\section{MATERIALS AND METHODS}

Self-administered questionnaire was employed to gather data for this study. The survey instrument was developed using several different questionnaires as a guide $^{[8,19,24]}$. First part of the questionnaire consists of thirty-eight items, which seek to know the perception of local managers towards their career advancement opportunities in their companies compared to their Japanese counterparts of the same standing. This covers six areas: perceived barriers of control of power and decision making authority, opportunities for promotion, benefits and compensation system, performance appraisal, feedback and lastly stereotype and discrimination. A five-point scale ranging from 1 (strongly disagree) to 7 (strongly agree) was employed. All the six perceived barriers have acceptable reliability estimates, the Cronbach's Alpha value ranged from .74 to .83 . The second part of the questionnaire seeks information on the company and respondent's background.

A pilot study was arranged with 30 local managers that were available to help with improvement of the questionnaire. Their feedback and comments led the questionnaire to be revised so that the final form of the questionnaire was deemed to consist of questions that all the respondents could be able to answer without difficulty. A reliability test on the questionnaire was undertaken using SPSS software and almost all the Cronbach's Alpha value were well above .70. Indeed, in some cases the alpha values were above .80 .

Having validated the questionnaire through pilot testing, a sample of 543 local managers working in both manufacturing and non-manufacturing Japanese subsidiaries in Malaysia were randomly selected from the list of "Japanese Related Companies in Malaysia" provided by Japanese External Trade Organization (JETRO). The survey was mailed to local managers at their respective subsidiaries. The response rate was initially not encouraging and thus reminders were sent out. Furthermore the researchers have made personal telephone calls to most of the respondents to improve the response rate. As a result, 317 valid responses were received which the researchers felt to be reasonable for this kind of study. Taking into account the invalid responses and undelivered survey, the response rate for this study was $69 \%$.

\section{RESULTS AND DISCUSSION}

Profile of the respondents: In line with expectation of the study, majority $(87 \%)$ of the respondents were male. As mentioned earlier In the Japanese subsidiaries, male employees are preferred compare to female employees $^{[19]}$. This is because female employees are not viewed as the core workforce but only the supporting staff. It has been a common scenario in Japan that a large number of women employees quit their job due to their family commitments ${ }^{[2,25]}$. On the other hand $55 \%$ of the local managers in this study were married. This perhaps shows the preference of Japanese subsidiaries, which are more towards family oriented personnel ${ }^{[8]}$. Majority of the managers who participated in this study were Chinese (43\%), followed by Malay (38\%), Indian $(15 \%)$ and $4 \%$ are other races. The managers fell into various age groups. The highest percentage, 35\% of managers fell in the range of 31 to 35 years of age, while the lowest percentage, $2 \%$ fell in the range of 51 years old and above. In term of academic qualification, $81 \%$ of the managers possess a bachelor's degree while the others were holding a Master degree.

Demographic factors and perceived barriers: The demographic factors involved in the first hypothesis testing were age, gender, race, educational background and marital status. The significant difference between perceived barriers for career advancement opportunities and demographic variables age, race and educational background were tested using one-way analysis of variance (ANOVA) while gender and marital status were tested using the independent sample t-test. The significant values ( $p$-values) noted for all the perceived barriers tested against marital status, race and educational background were higher than the alpha value of .05 . These indicate that there are no significant difference in perceived barriers between married and non-married; races; and educational background of the managers.

In terms of gender, women managers are perceived as less competent and in Japan very few women make up the core work force because they tend to quit after getting married and having children. Consistent with the findings in developing countries ${ }^{[10,24,26]}$ as well as in developed countries ${ }^{[27,28]}$ women employees were the minority and they held lower positions such as production workers. In this study, out of the 317 managers surveyed, only 41 were female managers; most of them were from lower management. Undoubtedly, there are barriers for women to advancement in their careers in Japanese subsidiaries in Malaysia, as well in other countries. They not only face the bias of being a local manager but also the bias of being a woman manager. Therefore, there exists dual bias and discrimination towards career advancement. This study also reveals that women managers felt their performance appraisals did not help them in their career advancement. Indeed there was a significant difference in the way male and female managers valued the importance of performance appraisal (perceived barriers) in the Japanese subsidiaries surveyed. The difference is statistically significant with $p$-value $=$ 0.041 . The male managers (mean $=23.77 ; \mathrm{SD}=3.96$ ) felt that performance appraisals played a more important role in their career advancement compared to 
the female managers (Mean $=22.37$; $\mathrm{SD}=4.88$ ). All the other perceived barriers did not show any significant difference with the demographic variable, gender (all the $p$-values $>.05$ ).

The ANOVA test between age and perceived barriers resulted that there is a significant difference in power $(F$-value $=3.083, p$-value $=0.006)$ and promotion $(F$-value $=3.633, p$-value $=0.002)$. A post hoc analysis, Turkey HSD was conducted for multiple comparisons for age. It was found that there is a significant difference between the variable power and the groups of managers aged less than 25 and between 41 to 50 years old. The managers from these age groups felt that they were entrusted with less power and decision-making authority in their organizations. Thus they believe that this would affect their career advancement opportunities. On the other hand, the result of the post hoc analysis for the variable promotion showed that there is a significant difference among managers in the age group of 41 years and above. The older managers that have been in the company for a longer time feel that they have fewer opportunities to promotion and career advancement in their Japanese subsidiaries.

Japanese subsidiaries are unique from other MNCs in terms of their human resource management and their style of seniority based promotion as well as hiring fresh graduates to mould them into valuable Japanese employees. Therefore, the age and gender of an employee may influence his or her chance to career advancement opportunities or serve to influence as a barrier. From the sample of this study, it can be seen that there is a small proportion of older long serving employees. There are only 18 managers over the age of 46 years old in the forty-one companies surveyed. Equally clear is the high proportion of workers in the middle-age category, 171 managers, between 31 to 40 years old. This generally shows, although there are a small proportion of older employees in this sample, it does not necessarily mean that many have worked in their companies for a long time. With regards to background, many of the managers have indicated working in other companies before joining the company but still a majority of them, sixty percent, have been working in the company for more than 6 years.

Raduan's ${ }^{[8]}$ findings showed that Japanese subsidiaries prefer older managers for two simple reasons. First, they regard older managers as being more experienced, rational and able to command respect from other employees. Therefore, older local managers are seen as father figures, trusted by other workers to attend to their problems whenever necessary. The Japanese employers adopt a paternalistic approach $^{[\dot{9}]}$. It is a means of establishing discipline in the organization. Older managers are also expected to have better communication skills and well-established contacts with the local government and outside agencies that need to be dealt with. Nevertheless, other studies such as Pascale and Athos ${ }^{[4]}$ also find that Japanese companies on the basis of a good academic background have recruited new generations of local managers. They recruit fresh graduates since late 1970 's and early 1980's by co-operating with the local university authorities to offer scholarships or jobs to these undergraduates. It can be seen that priority in recruiting and selection is given to students to be groomed for higher positions. Therefore, this may serve as a barrier for middle-aged local managers to join a Japanese subsidiary and be promoted. This is because of the competition from the younger managers, who have been in the company from the beginning of their careers. On the whole age and gender showed a significant relationship with career advancement opportunities for local managers in this study. Thus, the first hypothesis which states that there is no significant relationship between demographic factors and perceived barriers to career advancement could be have shown about the significant influence of demographic factors on perceived barriers to career advancement.

Characteristics of the organization and perceived barriers: From the 41 Japanese subsidiaries surveyed, 25 of the companies have been operating in Malaysia for less than 10 years while 16 companies have been operating for more than 10 years. $60 \%$ of the companies surveyed were fully owned by Japanese with 190 local managers and the balance $(40 \%)$ of the companies were joint venture with 127 local managers participating in the survey. For the purpose of this study, the number of employees available in a Japanese subsidiary determined its size. $14 \%$ of the companies surveyed had less than 100 employees, $35 \%$ had 101 to 500 employees, $23 \%$ had 501 to 1000 employees, 4 companies had 1001 to 1500 and 7 companies surveyed had more than 1500 employees. $71 \%$ of the surveyed companies were from manufacturing sector.

Four characteristics of the organization were taken into consideration to see whether it had any effect on perceived barriers. All the organizational variables involved were categorical type of data. The variables, type of ownership: fully Japanese or joint venture and the type of operation: manufacturing or nonmanufacturing was tested using the independent t-test. The variables, size and years in operation were tested using ANOVA because there were more than two groups involved. It was found that there is no significant difference in perceived barriers faced by managers in fully owned Japanese organization and joint-venture organization (all the $p$-values $>.05$ ). For the test against type of operation, a $p$-value of 0.011 was obtained which indicates that there is a significant difference in promotion faced by managers working in manufacturing and non-manufacturing organizations. Managers in the non-manufacturing sector felt that in term of promotion, they were less satisfied compared to mangers in the manufacturing companies. There were no significant difference between perceived barriers (power; benefits and wages; performance appraisal; feedback; and stereotype) and type of operation. All the $p$-values were found to be more than .05 .

The result from the ANOVA test between number of years in operation and performance appraisal (perceived barriers) indicated there is a significant difference $(F$-value $=5.331, p$-value $=.0001)$. From the post hoc analysis, it can be seen that in companies aged 20 years and more the local managers' perceive the performance appraisals as more positive compared to companies, which have been in operation for less than 20 years. It was also revealed that there were no significant difference between size of the organization and all the perceived barriers except for performance appraisal $(F$-value $=2.581, p$-value $=.0037)$. The post hoc analysis showed that managers in the companies classified as "big" (over 1000 employees) felt that their appraisals were important to their career advancement in terms of salary increment, job placement and promotional considerations. Overall results of the present study allow the second hypothesis to be rejected. In other words, there is significant relationship between characteristics of organization and perceived barriers to career advancement.

Consistent with the research done by $\operatorname{Raduan}^{[8]}$, this study does show a positive relationship with length of operation and size of the organization on perceived 
barriers and career advancement opportunities. The effects of length of operation and size of the subsidiary on human resource management (HRM) policies and practices as well as perceived barriers are well documented in the literature ${ }^{[27,30]}$. Several studies have found a significant relationship between decentralization and the length of operation and size of the subsidiary concluding that age and size of the subsidiary were the most significant factors in Japanese subsidiaries that are more decentralized are more willing to take risks on local managers compared to newer Japanese subsidiaries. This then reduces the barriers that local managers face in career advancement opportunities which has been cause by the decentralization phenomena.

Stereotype and discrimination and number of local managers in higher management positions: Out of the 317 local managers surveyed, $47 \%$ of them belonged to the lower level of management, $52 \%$ or 165 managers belonged to middle management and only $0.9 \%$ of the managers belonged to top management level. It also revealed that approximately $82 \%$ of the communication with parent company is made by the senior Japanese manager while the senior local manager did only $18 \%$. Other local managers handle $0.3 \%$ of the communication. The frequency of the communication is mostly either daily or weekly. $50 \%$ of the managers had daily communication, $43 \%$ had weekly communication and $7 \%$ had monthly communication with the parent company.

To test on the final hypothesis, ANOVA analysis was used to see whether there was a relationship between stereotyping and discrimination in the organization and the number of local managers that are making it to higher management positions. Perceived barrier, stereotype and discrimination, used the interval type of data while number of local managers used the categorical type of data. The results indicated that there is indeed a significant relationship between the mean scores for stereotype and discrimination and number of local managers $(F$-value $=2.913, p$-value $=.0035)$. Local managers felt that they are being discriminated against opportunities for higher management positions in Japanese subsidiaries in Malaysia. From the post hoc output, the number of local managers between 1 to 20 , 41 to 60 and 61 to 80 all showed a significant difference with stereotype and discrimination. Thus, the hypothesis, which proposes that there is no significant relationship between the extent of stereotyping and discrimination in the organizations and the number of local managers in higher management positions in Japanese subsidiaries, was rejected

Similar to previous studies ${ }^{[\dot{8}, 924,26,32]}$, this study revealed that, stereotyping and discrimination does play a role in the number of local managers in higher management positions and creates the problem of ethnocentrism in the organization. Ethnocentrism is the emotional attitude that Japanese subsidiaries have about their own nation; culture and that Japanese manager are far superior to the local workforce. Beamish and Inkpen $^{21]}$, found that Japanese subsidiaries filter local managers from higher management positions based on the stereotype that local managers are too inferior to handle authority compared to the Japanese managers. At the same time these authors stated that stereotype and discrimination are decreasing due to the gradual decreasing number of Japanese expatriates and dismantle of the "the rice paper ceiling". Nevertheless, a more recent study conducted by Harrington ${ }^{[32]}$ showed that there is indeed a strong relationship between discrimination and the number of local managers in higher management positions. The study carried out in Japanese subsidiaries in the United States contradicts Beamish and Inkpen's study done in 1998, which states that there is a decline in Japanese expatriates. It was also noted that ethnocentrism in Japanese subsidiaries greatly preventing local managers from climbing to higher management positions. On the whole, majority of the findings showed that the existence of stereotyping and discrimination has an impact on the number of local managers in higher management positions in Japanese subsidiaries. This scenario is still evident in Japanese subsidiaries in Malaysia until today.

\section{CONCLUSION}

Japanese MNCs have been operating in Malaysia for long time and yet not many studies have been conducted on them and their activities in this country. Apart from management issues, problems faced by local managers are vital issues related to MNCs that needs to be addressed and researched intensively on a continual basis. This is because without local managers, Japanese MNCs would not be able to maintain and operate the subsidiary in accordance to their objectives and strategies in the near future. Local managers could be seen as one of the backbones that critically support the management of the Japanese subsidiaries if they are given equal opportunities in advancement. In this study, it was found that there is a significant relationship between demographic factors and its influence on perceived barriers to career advancement. The significant demographic factors were age and gender. The second part of the analysis found that there is a significant relationship between characteristics of the organization and its influence on perceived barriers to career advancement. The significant characteristics of the organization were size of the organization, age or years of operation and type of ownership. The last analysis revealed that there was a significant relationship between stereotype and discrimination and the number of local managers in higher management positions. Due to stereotyping and discrimination in Japanese subsidiaries, there are relatively fewer local managers advancing to higher management positions.

If Japanese firms refuse to allow non-Japanese managers into top executive positions in their subsidiaries, the problem of ethnocentrism will continue to prevail. Moreover if the trend does reflect a shift in Japanese firm's management practices, there will be two important implications. First, there will be more management opportunities in Japanese subsidiaries for non-Japanese and by implication, even more competition for the existing supply of effective global managers. The second implication is that this trend represents a move towards genuine globalization for Japanese firms. On the assumption that localization improves subsidiary performances, many Japanese firms will become even stronger international competitors. For their North American, European and Asian competitors, it will serve as a wake-up call.

Japanese firms stand to lose out in the competition for global talent, if these corporations are reluctant to consider foreign talent for higher managerial positions. This is because the most talented people will not join an organization that holds out on no promise of promotion. Japanese owned corporations that have been notoriously slow to open their top executive ranks to non-Japanese will operate at a competitive disadvantage. Although it is too early to tell if Japanese firms are willing to open the most senior executive positions to non-Japanese, this research shows that at the subsidiary level, Japanese firms are still putting barriers to make it hard for local managers to advance. 
There are two possible future scenarios associated with Japanese MNCs, their use of expatriates and their role in global business. According to Beamish and Inkpen $^{219}$, a possible scenario for Japanese FDI could unfold as follows. As Japanese firms continue to expand internationally, the shortage of qualified Japanese expatriates will force Japanese firms to hire more local managers for senior managerial positions. Enlightened firms also realize that the "rice paper ceiling" is an obsolete concept. Over time, Japanese MNCs will shed their ethnocentric biased attitude and hire the best managers they can find, Japanese or nonJapanese. Non-Japanese managers will find their way to the most senior executive ranks. As a result, Japanese MNCs become even stronger competitors around the world. This is a possibility that seems very far in the future, especially for developing countries like Malaysia, with developing local expertise in Malaysia. An alternative scenario is far less positive from a Japanese firm's perspective. The inability to find high quality expatriates and the reluctance to abandon an ethnocentric view will limit Japanese MNCs' ability to grow. The increasing use of local managers will impact only middle and lower managerial levels. Top management positions in both headquarters and subsidiaries will reserve for Japanese nationals. As a result, Japanese FDI will stagnate and probably decline. Japanese firms will gradually play a less important role in the global environment.

\section{Research issues to be addressed}

* If there is greater use of local managers, will Japanese firms be more willing to engage in international mergers and acquisitions?

* To what extent do Japanese subsidiaries want to eliminate the barriers local managers face and are interested in transferring knowledge to help educate local managers in developing countries like Malaysia?

\section{REFERENCES}

1. Abegglen, J.C., 1958. The Japanese Factory: Aspects of its social organization, The Free Press.

2. Clark, R., 1979. The Japanese company. New Haven, Yale University Press.

3. Cole, R., 1971. Japanese blue collar. Berkerly, University of California.

4. Pascale, R.T. and A.G. Athos, 1982. The Art of Japanese Management. London: Allen Lane.

5. Ouchi, W., 1981. Theory Z. Addison-Wesley, Reading, MA.

6. Oliver, N. and B. Wilkinson, 1988. The Japanization of the British Industry. Basil Blackwell, Oxford.

7. Raduan, C.R., 2001. The transfer of Japanese-style management abroad. Paper presented at the AsiaPacific Business Conference, Michigan, USA.

8. Raduan, C.R., 2002. Japanese style management abroad: The case of Malaysian subsidiaries. Prentice Hall, Pearson Education Malaysia.

9. Tsuda, M., 1981. Perspective of Lifetime Employment Security Practices in the Japanese Enterprise. In Ishikawa, A., and Woodhouse, T. Employment and Participation: Industrial Democracy in Crisis. Tokyo: Chuo University.

10. Imaoka, H., 1986. Japanese management in Malaysia. Southeast Asian Studies, 22: 339-357.

11. Elger, T. and C. Smith, 1994. Global Japanization? The transnational transformation of the labor process. London: Routledge

12. Ichimura, S., 1981. Japanese enterprises in Asia. Tokyo: Tokyo Keizai Shimposha.
13. Negandhi, A., E. Yuen and G. Eshgi, 1987. Localization of Japanese subsidiaries in Southeast Asia. Asia Pacific J. Manag., 5: 67-79.

14. Yoshino, M.Y., 1975. Emerging Japanese Multinational Enterprises. In E.F. Vogel (Ed.). Modern Japanese Organization and DecisionMaking, pp: 46-166, Berkeley, C.A.: University of California Press.

15. Lawler, J., S. Siengthai and V. Atmiyanandana, 1998. HRM in Thailand: Eroding Traditions. In Chris Rowley (ed.) Human Resource Management in the Asia Pacific Region. Convergence Questioned. London: Frank Class.

16. Graham, L., 1995. On the line as Subaru-Isuzu: The Japanese Model and the American Worker. New York: ILR/ Cornell UP.

17. Kobayashi, N., 1985. The patterns of management style developing in Japanese multinationals in the 1980's. In Takamiya, S., and Thurley, K. (Eds), Japan's emerging multinationals: An international comparison of policies and practices. Tokyo: University Tokyo Press, pp: 229-264.

18. Hayashi, K., 1986. Cross-cultural interface management in America: What does and doesn't work? Natl. Product. Rev., pp: 61-74.

19. Kopp, R., 1994. The Rice Paper Ceiling: Breaking through Japanese corporate culture. Berkeley, CA: Stone Bridge Press.

20. Balliga, B. and J. Jaeger, 1984. Multinational corporations: Control systems and delegation issues. J. Intl. Business Studies, pp: 25-39.

21. Beamish, P.W. and A.C. Inkpen, 1998. Japanese firms and the decline of the Japanese expatriate. J. World Business, 33: 35-51.

22. DeNero, H., 1990. Creating the 'Hyphenated' corporation. McKinsey Quarterly, 4: 153-174.

23. Kranias, S.D., 200). Cultural control: The case of Japanese multinational companies and their subsidiaries in the UK. Management Decision, 38: 638-649.

24. Abdullah, S. and T. Keenoy, 1995. Japanese managerial practices in Malaysian Electronics Industry: Two case studies. J. Manag. Studies, 32: 747-766.

25. Dedoussis, V., 1995. Simply a question of cultural barriers? The search of new perspectives in the transfer of Japanese management practices. J. Manag. Studies, 32: 731-746.

26. Amante, M., 1993. Human resource management in Japanese enterprise in the Phillipines: Issues and problems. Asia Pacific J. Manag., 10: 237-245.

27. Dunning, J., 1986. Japanese participation in British industry. Croom Helm, London.

28. Offermann, L.R. and C. Beil, 1992. Achievement styles of women leaders and their peers. Psychol. Women Quarterly, 16: 37-56.

29. Sohn, J.H.D. and Y. Paik, 1996. More is better? Expatriate managers and MNCs' ability to control international subsidiaries. Working Paper.

30. Sim, A.B., 1977. Decentralized management of subsidiaries and their performance. Manag. Intl. Rev., 17: 45-51.

31. Gapper, J., 1994. Taking Japan out of Nomura International - The broker is quietly restructuring its European arm to serve clients better and shift the power away from Tokyo. Financial Times, April 14,30.

32. Harrington, J., 2001 The Japanese by-standards. Manag. Sci., 44: 349. 